\title{
Forest Conservation in the Tropics - a Case from Ethiopia
}

\author{
Klaus Müller-Hohenstein \& Asferachew Abate
}

Key words: conservation concept, tropical forests, an Ethiopian case, combining approaches from the natural and the social sciences, interdisciplinarity, integration.

\section{Abstract}

Despite all the efforts of politicians and scientists to protect tropical forests, the degradation of these ecosystems continues unabated. Based on experiences with tropical forests and on detailed studies of an Ethiopian mountain rain forest, we discuss previous failures and omissions. On the one hand, people have tried to establish and manage protected areas on a one-sided basis, often exclusively from the natural sciences. On the other hand, the population directly affected by the establishment of a protected area has not been involved in planning or management and not been compensated for any losses. We call for an integrated approach to research, with biologists and ecologists as well as social scientists and economists working together on a feasible conservation concept. The political framework needs to be taken into account but even more important is getting the local population involved in every step of the planning process and compensating them for the loss of utilization rights and resources.
Profile

Protected area

Munessa Shashamene Forest

Mountain range

Eastern escarpment of the Great

Rift Valley

Country

Ethiopia

\section{Introduction}

The degradation of tropical and subtropical forests has been documented for quite some time (Engelhardt 1984). It goes hand in hand with the continuous decline of biodiversity in these habitats (DuToit et al. 2004; Bruner et al. 2001). Without forest conservation there can be no climate protection (Stern Review 2008). These forests are predominantly located in developing countries, where the local population relies on utilizing these resources. Many protected areas have been designated in these regions (World Conservation Monitoring Centre: www.unep-wcmc.org), but the acreage of natural forests continues to decline (Hirschberger 2007).

Why is it that the actual protection of tropical forests shows so little success despite numerous efforts? Who is degrading the forests? Are national and international organizations interested in concrete protection efforts beyond establishing conventions? Are scientists aware of their responsibilities? Numerous actors have an interest in conservation. Below we shall focus on scientists and the most affected local population (Figure 1). Our observations are based on our own studies and our detailed knowledge of the current situation in several protected areas in Africa and South America. The most comprehensible data available to us stem from our work in Ethiopian national parks (MüllerHohenstein \& Abate 2004). Using the suggestions for an RRA (Rapid Rural Appraisal) as proposed by Schönhuth and Kievelitz (1994), we interviewed all involved groups in our study area, from national ministry officials to all age groups of the rural population.

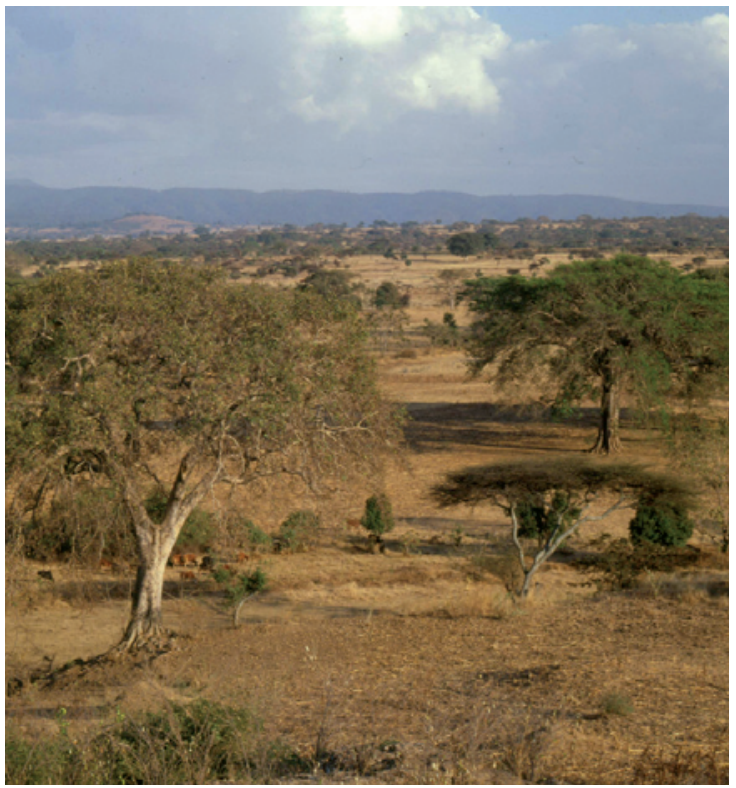

Picture 1 - Isolated large fig trees (e.g. Ficus sycomorus, Ficus vasta) on land mainly used for growing cereals are characteristic for the vegetation of the "lowland savanna" (altitude ca. $1700 \mathrm{~m}$ ).

\section{The current situation: failures and require- ments}

Often it is lack of information from the natural sciences that is responsible for the failure of conservation efforts. We do not, for instance, have any comprehensive inventories of flora and fauna of the Ethiopian national parks in the Rift Valley. Social scientists are called for to improve in particular the scant knowledge 


\section{PROTECTED AREA}

\begin{tabular}{|c|c|}
\hline $\begin{array}{c}\text { Scientists from the humani- } \\
\text { ties and social sciences }\end{array}$ & $\begin{array}{c}\text { Users - decision-makers } \\
\text { Ethnologists } \\
\text { Economists } \\
\text { Technicians } \\
\text { Social scientists } \\
\text { Agricultural economists }\end{array} \quad \begin{array}{c}\text { Politicians at all state levels } \\
\text { Private, cooperative, } \\
\text { (national, regional, local) } \\
\text { and national institutions } \\
\text { and their advisers } \\
\text { Regional planners }\end{array}$ \\
\hline
\end{tabular}

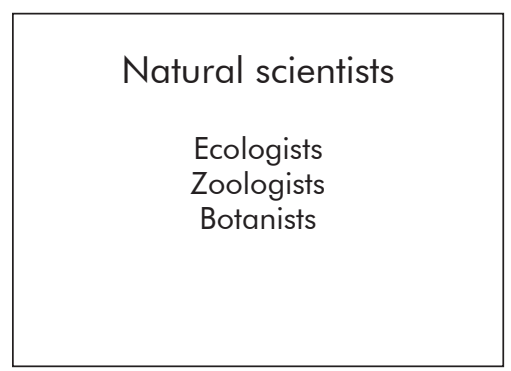

Figure 1 - Key actors in conservation planning

on the socio-cultural and economic environment of the conservation object. In addition, efforts should be made to strengthen the political will of the relevant decision-makers.

Conservation aims to protect and link up habitats, to regenerate them if necessary and to provide adequate scope for them to flourish. Rarely has anyone recognized the highly complex nature of developing conservation concepts. At the AGMs of the German Society for Tropical Ecology, with dozens of papers and posters, such issues hardly register. Regrettably the „Tropenökologische Begleitprogramm“ of the GTZ, in which scientists and practitioners worked on conservation in developing countries, has been closed down. Only a combination of approaches and findings from the natural and social sciences promises to deliver here $\left(1^{\text {st }}\right.$ thesis). For planning to succeed, it must not only consider the regional and local natural environment, but also the social, economic, cultural and political situation. This means interdisciplinary cooperation of scientists who are prepared to see their own discipline occasionally in a subordinate position. Such a joint approach is needed to develop a theoretical basis.

Moreover, stakeholders of the immediately affected local population must be given the opportunity for active participation in debates and decisions ( $2^{\text {nd }}$ thesis). Geography in particular holds great potential for dealing with such a complex theme, but only if representatives from physical and human geography join forces in their search for solutions ( $3^{\text {rd }}$ thesis).

The efforts of international organizations to establish conservation programmes go back many years, with a focus on tropical forests. The WWF (since 1961) and Greenpeace (since 1971) have contributed greatly to raising awareness of the protection of these ecosystems. In 1971 UNESCO created the preconditions for creating biosphere reserves by establishing the MAB (Man and the Biosphere) programme. Until today the Convention on International Trade in Endangered Species of Wild Fauna and Flora (CITES) of 1973 and other international plans of action and conventions (CBD, Rio de Janeiro 1992) are important preconditions for conservation efforts. In some countries, however, these conventions are all but unknown, in others - as in Ethiopia - regulations and guidelines for their implementation are lacking. In Germany guidelines for conserving tropical rain forests were formulated as early as the 1980s (BMZ 1988), on the assumption that protecting forest ecosystems is an important aspect of development cooperation and that conservation must be taken into account in comprehensive regional planning (Richter 1991).

\section{A case in point: the Munessa Shashamene Forest}

To illustrate our theses formulated above and as an example of a promising approach, we have chosen one of the last extensive forest areas in south-eastern Ethiopia, the Munessa Shashamene Forest. We shall use this case to debate typical issues that need to be resolved if a conservation concept is to be implemented successfully. This tropical montane forest is situated in the Arusi Zone of the Oromia region, some $250 \mathrm{~km}$ southeast of Addis Ababa, on the west-facing slope of the eastern edge of the Great Rift Valley, at altitudes between 1700 and $2700 \mathrm{~m}$ (ca. $\left.7^{\circ} 40^{\prime} \mathrm{N}, 39^{\circ} 10^{\prime} \mathrm{E}\right)$. It is bordered on its western edge in the Great Rift Valley by a "lowland savannah" with remnants of Acacia croton woodlands within mainly cereal growing areas (Picture 1). At higher altitudes it is bordered in the East by a "mountain savannah" with isolated woodlands within pastures that indicate former Hagenia - Juniperus forests (Picture 2). In the continuous forest within these boundaries, mainly large tracts of Eucalyptus div. spec. and Cupressus lusitanica have been planted at lower altitudes (Picture 3), higher up natural forests prevail, with Podocarpus falcatus as main tree species (Picture 4). At the edge of the forest in particular, these stocks are severely degraded. Figure 2 shows a schematic W/E transect of the Munessa Shashamene Forest and its neighbouring landscapes, taken from Müller-Hohenstein and Abate 2004.

Depending on the relief and the different climate and soil conditions that go with it, several floristically different forest communities have emerged. They are among the last such forests that remain relatively undisturbed. At the moment their conservation is not guaranteed. The local population lives predominantly on the fringes of the forest, with some living actually in the forest. They mainly grow traditional indigenous crops (e.g. teff, ensete) and keep local breeds of cat- 


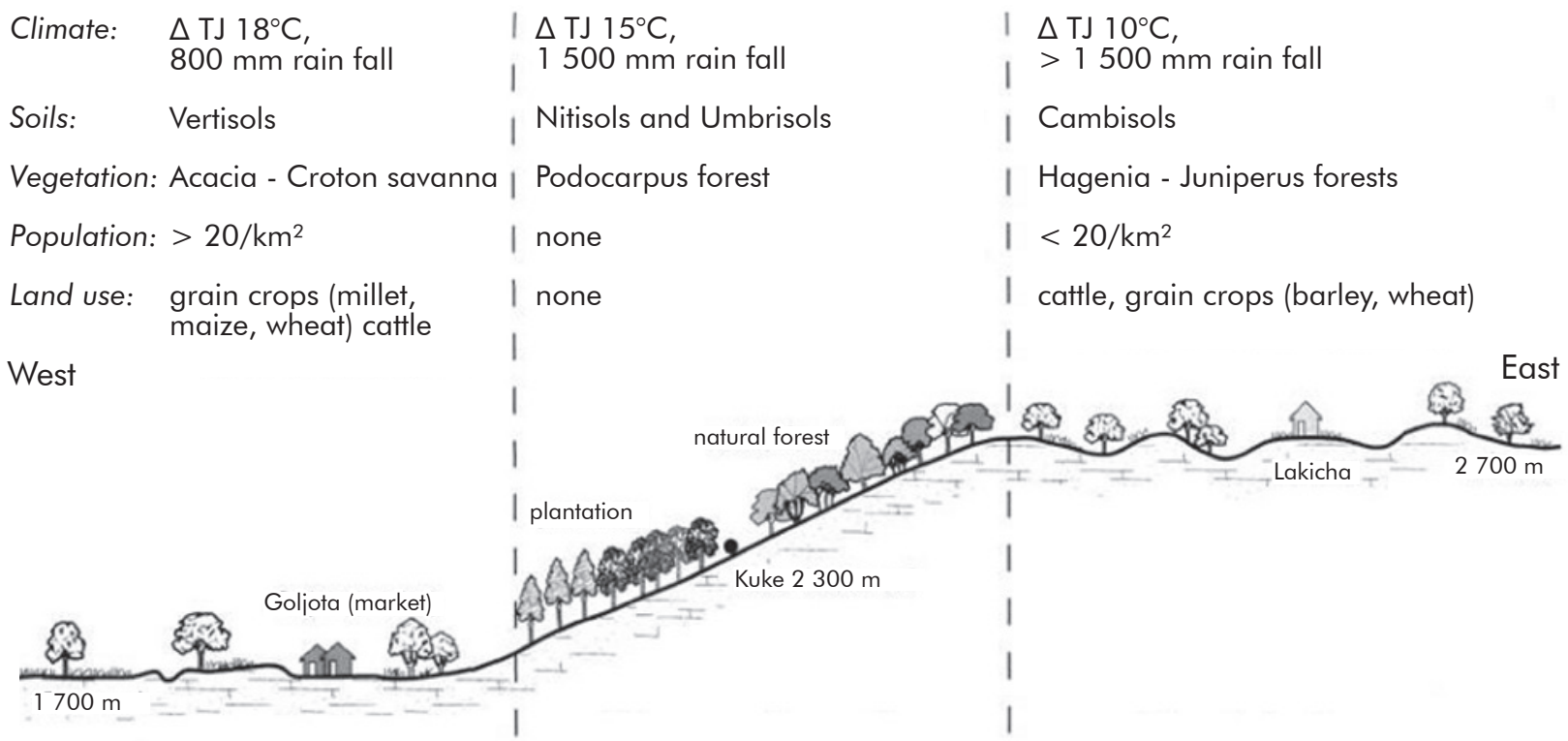

\section{Lowland savanna "Munessa Shashamene Forest" Mountain savanna}

Figure 2 - Schematic W/E profile of the Munessa Shashamene Forest and the neighbouring landscapes of the "lowland" and the "mountain savanna"

tle. The fast growing local population depends heavily on the forests and their products, putting them under severe pressure. Utilization of the state-owned forests is prohibited (EPA 1997). The reforestation as well as the remnants of natural woodland are (supposed to be) controlled by a state company, but despite that the area of natural forest continues to shrink. Pictures 5-8 show examples of the deepening degradation of the forests.

\section{The path towards a conservation concept: options}

In order to develop a conservation concept, we must first answer questions from two completely different areas. The overall question for the first area is: what is it that should be protected and why? The second question is: who protects the forest from whom and how do they go about it? Only if we have answers to both questions can we use them to build a workable conservation concept.

What is it that should be protected and why? First of all we must ascertain whether the proposed biocoenoses are in need of protection. In the case of a forest this entails finding out if there are any comparable forests in the region or in the country or anywhere at all; if rare and/or endangered plant and/or animal species live in these forests and if they fall into nationally or internationally valid conservation categories. Our example - along with stocks in Kenia - is among the last remaining larger podocarpus forests in East Africa and therefore one of the UN High Conservation Value Forests.

The first general question concerns mainly the natural sciences. A detailed inventory of the biocoenoses is needed. Botanists, zoologists, geo-ecologists must try to establish substantive labelling and spatially delimit the potential protected area. In our case scientific literature only classifies the Munessa Shashamene Forest roughly as a podocarpus forest community (Friis 1992). There are no more specialized vegetation studies or faunistic surveys. In many tropical areas the data situation is likely to be similar.

We should investigate forest communities using plantsociological techniques based on Braun-Blanqet or modified versions thereof. Special attention should be paid to the types and extent of interventions, e.g. through grazing and selective felling. Structural features of the vegetation should be included in the survey. One goal must be to draw up large-scale maps that show the distribution of the identified communities, the degree of degradation, their rarity and their sensitivity towards interventions (Loidi 1994). In the case of the Munessa Shashamene Forest, degraded stocks may be identified using grazing indicators and herbaceous species introduced by the cattle from outside the forest.

Forests however are biocoenoses, their fauna must be taken into account. For many groups this is difficult if not impossible, because the current state of research does not allow it. Only for "attractive" groups, such as large mammals and birds, do we have relatively comprehensive lists of species. It is especially important to gather details on species or groups of animals living in biocoenotic connection with plants, for instance as pollinators or distribution vectors.

Location conditions, major climate and edaphic data must also be collected. This includes the likelihood of frosts, the amount and distribution of precipitation, local climatological particularities as well as identifying a possible scarcity of macro- or micronutrients or soil physical data that greatly influence water circulation and availability. It is important to know the spatial dimension of ecotopes and ecotope structures. On the 


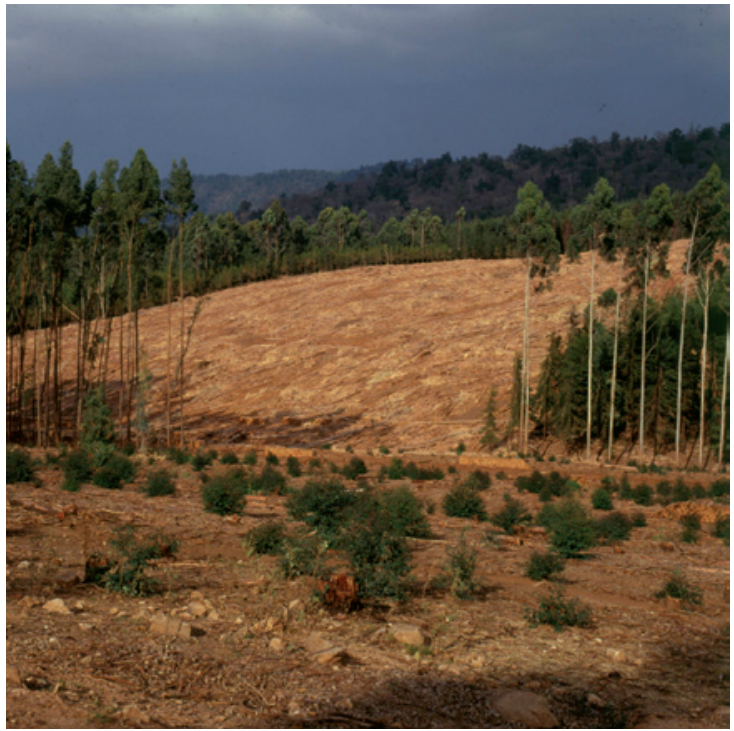

Picture $2-$ On the lower slopes of the eastern rim of the Rift Valley, reforestation with exotic tree species (e.g. Cupressus lusitanica, Eucalyptus saligna) in the Munessa forest is replacing the natural woodland.

basis of this initial work one can determine the location and size of the least disturbed forests, which are most worthy of protection.

It is not enough to gain a general idea of the problems of designating a protected area, in addition several specialists are needed. Questions remain in faunistic research and about the forest communities. What are the temporal dynamics of these forests, which are the pioneer and mature forest species? Is regeneration possible, i) vegetatively, ii) by introducing diasporas, or iii) from the seed bank? Which vectors are essential for their distribution? Answers to these questions provide important pointers for a feasible protection of the proposed habitats.

Who should protect the identified forests from whom and how do they go about it?

Arguments from the natural sciences alone will not suffice to develop feasible conservation, let alone implement it. Answers to the second issue need to be found mainly by the social sciences. We need to know who is going to be responsible for such protection and who can really guarantee it.

In the Environmental Policy of Ethiopia (1997) it says: "The last natural forests of Ethiopia should either be protected or managed and used in a sustainable way." In many documents the government and NGOs deplore the lack of conservation concepts due to a scarcity of experts and funds. This shows a typical and wide-spread dilemma that also exists in our case. The legal framework and basic conservation requirements have been formulated, even regulatory statutes are often in place, but successful implementation has not happened. There are gene banks to store large collections ex situ. Big game in national parks is often comprehensively protected, not least because of the

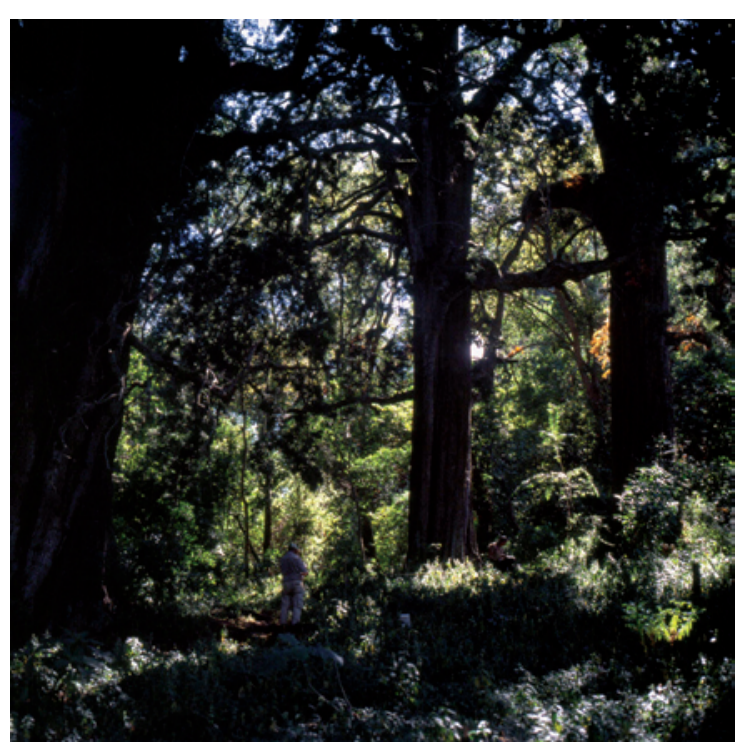

Picture 3 - On the central and upper slopes some only slightly degraded natural woodlands remain, with podocarpus (Podocarpus falcatus) as the dominant tree species.

income from hunting and tourism that is connected with it. However, designating a protected area and managing it successfully can only be achieved on the basis of an analysis of all people, groups and institutions involved in protecting the forests and in the knowledge of their actual responsibilities, possibilities and interests. General bans, even if they are backed by the threat of drastic penalties, are insufficient.

The level of the state, however, is only one level of decision-making and not even the most important one when it comes to real success on the ground. More important are the local population groups who live in the proposed conservation area, in our example also a national forest enterprise. If the local population degrades the forest through its economic activities, it is not driven by the desire to maximize profit, but because, with increasing numbers of people, it needs the forest products to survive. Conflicts with the state-run forest enterprise, which is using fast-growing exotic trees for afforestation, are inevitable.

The causes of the ongoing destruction of forests can often be found in an insecure legal situation as regards land ownership and utilization rights, contested distribution of lands, exclusion from decision-making on land use and lack of compensation for the withdrawal of utilization options. We are thus confronted with socio-economic and political aspects. One key term in this respect is "participation". It is imperative to actively involve all interested and affected groups in decisions on the spatial dimension and substantive definition of a future conservation area. SteinhauerBurkart and Fischer (1996), Sombroek (1994), and Sawhney and Engel (2002) have shown this for tropical forests from around the world.

Our interviews showed clearly how difficult negotiations are between partners who have not previously 


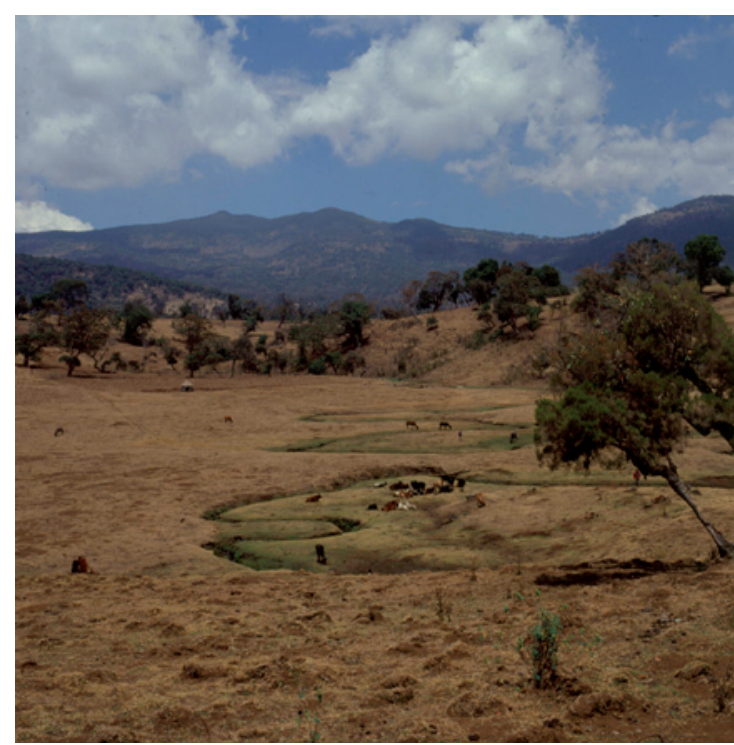

Picture 4 - In the "mountain savanna" (at ca. $2700 \mathrm{~m}$ ) isolated groups of Hagenia abyssinica and Juniperus procera trees remain in an area mainly used for grazing.

known dialogue at eye level. In this context "compensation" is another key term. It is necessary to clarify what kinds of land use are possible, how the population will satisfy their demand for firewood, timber and medicinal plants, and where their animals shall graze. One needs to check if the agricultural potential has been exhausted, if better seeds, different cultural plants with a higher yield, more productive animal breeds or agroforestry elements may be introduced and irrigation plots established. One possible step in terms of "protection through utilization" could be a transfer of ownership of forest areas or trees to the local population. Testing a community forest concept might pro-mise success (Galvin \& Haller 2008). It seems that direct ownership is the strongest motivation for sustainable use and protection. It is also necessary to find out if alternative income can be generated, e.g. through tourism, local trades or via micro-loans within fair-trade setups. Acceptable solutions can only be reached in appropriate agreements on access and benefit sharing.

\section{Initial building blocks of a conservation concept}

Ideas about conservation objectives have changed repeatedly in the recent past (Plachter et al. 2002). Tropical forests need the most comprehensible protection of biocoenoses in their habitats, i.e. the protection of complete ecosystems. Models that promise such protection, particularly in areas where the local population depends on agriculture and forestry for their livelihood, are based on zones of different types of utilization and zones in which no interference is permitted. We can call this concept "ecological-economic zoning". Such a multi-zone protected area consists of

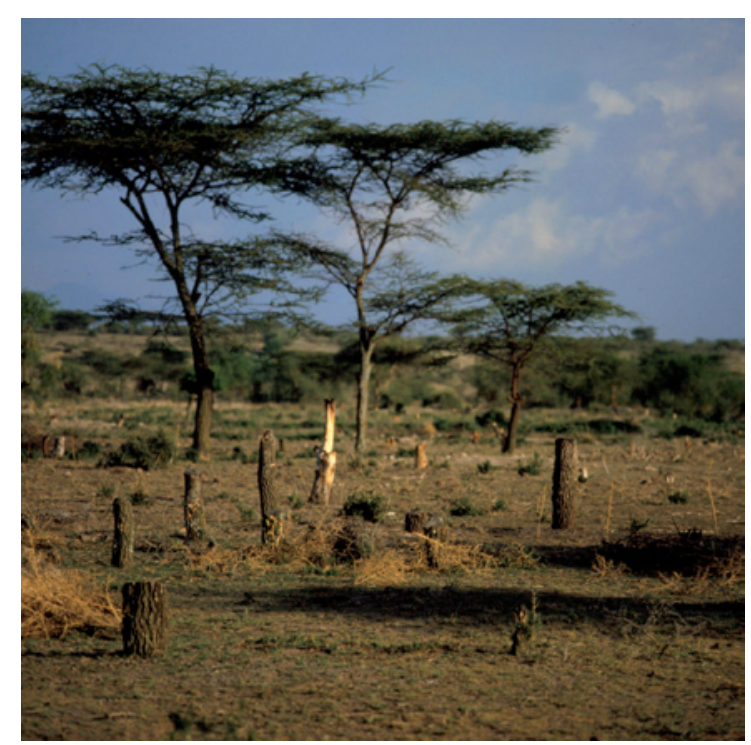

Picture 5 - Former continuous acacia stocks in large areas of the "lowland savanna" are being increasingly degraded and decimated due to charcoal production.

zones to be protected and zones that may be utilized on the basis of certain agreements, provided the affected population has been included in decisions on the spatial dimension and substantive definition of those zones (IUCN 1997).

In the case of the southern Ethiopian forest area we are assuming four designated zones: a core zone, protected and surrounded by up to three buffer zones. The results of two separate scientific debates should feed into their designation. One of these debates centres on the issue of the required minimum size of such a protected area and if in some situations several small areas with identical content and functions might not work just as well as one larger area (Amend \& Amend 2000; Stadler 2000; Sombroek 1994). This so-called SLOSS (single large or several small) debate may be an important theoretical background in many cases but rarely plays a role in practice due to a lack of choices. The same is true of the MVP (minimal viable population) debate based on a minimum number of procreative organisms of a species that would ensure the continued existence of that species (Shaffer 1981; Simberloff \& Abele 1975; Shafer 1990). In practice and also in our case, national and local politics and the economic framework play a bigger role.

The core zone is mainly designated on the basis of vegetation studies (particularly plant-sociological surveys). It contains the "best" current forest stocks with the least degradation. It is an area of absolute protection. Only scientific observation, e.g. on the regeneration of stocks, is permitted. Any degrading interference is strictly prohibited.

In the first buffer zone, settlements are not allowed, nor agricultural activities, especially no grazing. In these less degraded forests, forms of sustainable forest management with indigenous tree species, experi- 


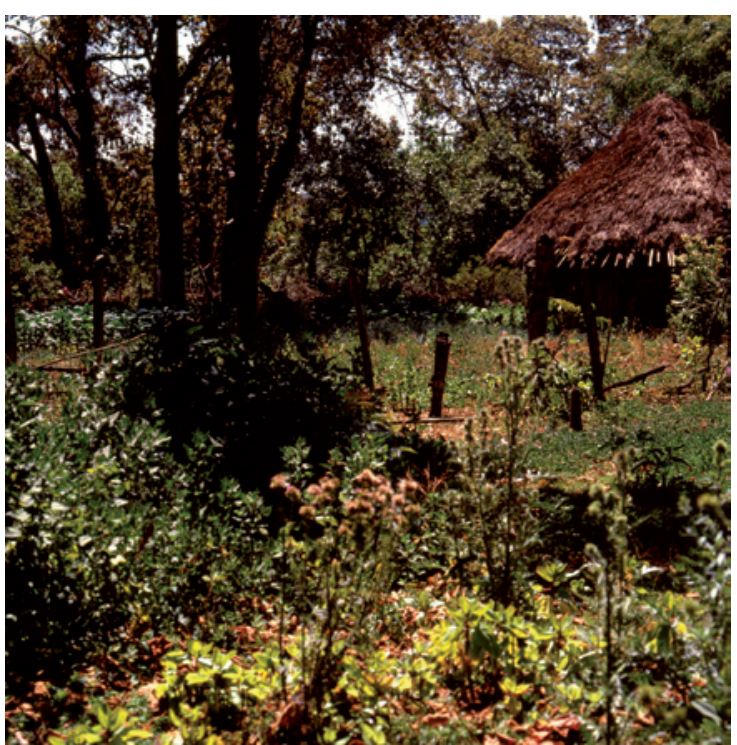

Picture 6 - In the remaining natural woodlands more and more illegal settlements are created and land is cleared for domestic gardens.

ments in enrichment, and adapted silvicultural measures, need to be developed. The second buffer zone with traditional rural settlements is the place for agroecological experiments. We could envisage tests with agro-forestry elements, such as those that have been successfully established in land-use systems in the larger surroundings of the protected area. Increased production may be expected here. Cultivation in the private gardens of the settlements may be intensified as may be animal husbandry. In the third buffer zone relatively extensive agriculture and plantations of exotic tree species (particularly eucalyptus and cupressus) exist today. Careful selection of seeds and animal breeds plus adapted pasture management should yield improvements here. Small forest plantations may partially compensate the population for losses of existing degraded forests and provide a monetary income.

At the end of such surveys and reflections a detailed map of the selected protected area and its buffer zones must be drawn up that all stakeholders can accept in its proposed dimensions and substantive composition. This brief sketch demonstrates i) how many disciplines need to be involved in developing such a complex concept; ii) that the representatives of these disciplines must work closely together, and iii) that it can only be implemented successfully, if the affected population participates in the concept.

\section{Conclusion}

Our findings show that because of the great complexity of conservation projects they can only succeed through close cooperation between all academic disciplines involved as well as with the relevant decisionmakers and most of all with the local residents $\left(1^{\text {st }}\right.$ thesis). This view is shared inter alia by colleagues at the Centre for Environmental Research (UFZ) in Leipzig

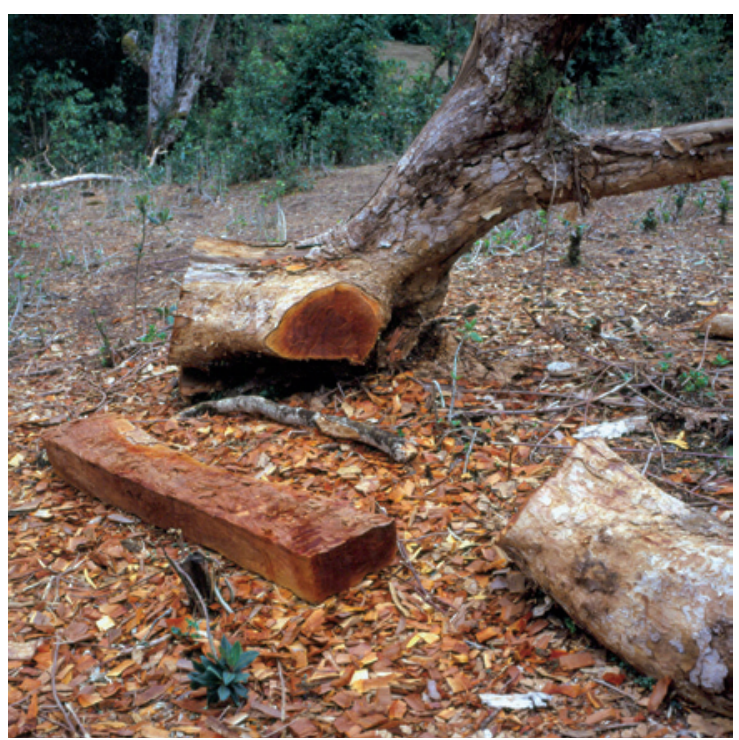

Picture 7 - Large felled trees of various species are processed in situ with simple axes into planks for building houses and bridges, which are sold on the highways.

who state that results can only be achieved by "close interaction of natural and social science disciplines" (Teutsch 2008, p.3). The demand for genuine interdisciplinarity is currently voiced more by social than by natural scientists. As Drenth (2008, p. 39) put it: "Disciplines vary in content, issues and methods. But there are also quite some common objectives, interests and concerns, the most important of which may be the common goal of searching for testable truth with objective and independent evidence. The communalities render it possible, or even imperative, to communicate and to cooperate. The diversity implies complementariness and calls for interdisciplinarity in the study of today's numerous and complex phenomena in science and society."

This reluctance to work together does not just exist between natural and social scientists but also between scientists and practitioners. Scientists often provide findings expressed in overambitious language that an interested practitioner can hardly understand, but he or she will only rarely dare ask the scientist for clarification. This tension between academic aspirations and relevance for the people on the ground must be resolved. Scientists should be capable of "working out solutions that are suitable for practical implementation and considered decision-making," (Teutsch 2008, p.3). We want to emphasize that scientists alone cannot come up with a promising conservation concept. It needs close cooperation with national institutions and most of all with the affected population ( $2^{\text {nd }}$ thesis). In social geography there have recently been calls for and concrete examples of "interface research" (Schnittstellenforschung). In our view, conservation issues are a fitting subject for such transdisciplinary interface research. This field of research holds great opportunities for finding out why cooperation between the natural and social sciences is so difficult and for 
identifying those interfaces that might help overcome these difficulties. Here the search is on for fundamentally new theoretical approaches.

Under the heading of geography, natural and social scientists meet and should be able to offer solutions for conservation concepts developed in such transdisciplinary cooperation ( $3^{\text {rd }}$ thesis). In recent decades the two main strands within geography have grown apart, but there is a proposal which shows a feasible way of working together. Weichhardt's (2005) "three pillars model” (Drei-Säulen-Modell) posits social and environmental research as the missing link between physical geography and human geography. Important findings have come from Bohle (2005) in the field of "environment and health" and from Müller-Mahn (2005) in "natural catastrophe research". Our case of developing a conservation concept for tropical forests in developing countries may also be seen as an example of such interface research. As yet no overarching methodologies have been established, but this should not stop practice-oriented geographers from taking up urgent conservation issues in developing countries. To date we have not fully realized the requirements in this area and have missed some opportunities.

\section{Acknowledgements}

Our thanks go to the Deutsche Forschungsgemeinschaft, which funded part of our work in Ethiopia, as well as our Ethiopian and German colleagues in the Munessa Shashamene Project for the friendly cooperation. Special thanks are due to the population of the area, who always welcomed and supported us.

\section{References}

Amend, T. \& S. Amend 2000. Zonierung von Schutzgebieten. In: GTZ (Deutsche Gesellschaft für Technische Zusammenarbeit \& BfN (Bundesamt für Naturschutz) Internationale Naturschutzakademie Insel Vilm (eds.). Naturschutz in Entwicklungsländern. Neue Ansätze für den Erhalt der biologischen V ielfalt. Heidelberg: 95-105.

Amente, G. 2005. Rehabilitation and sustainable use of degraded community forests in the Bale Mountains. $\mathrm{PhD}$ thesis. Albert-Ludwig-Universität Freiburg.

BMZ (Bundesministerium für wirtschaftliche Zusammenarbeit) (ed.) 1988. Erhaltung der tropischen Regenwälder. BMZ-aktuell, Bonn.

BMZ (Bundesministerium für wirtschaftliche Zusammenarbeit) (ed.) 2008. Biologische Vielfalt. Konzepte 164, Referat 312, Bonn.

Bohle, H-G. 2005. Umwelt und Gesundheit als geographisches Integrationsthema. In: Müller-Mahn, D. \& U. Wardenga (eds.), Möglichkeiten und Grenzen integrativer Forschungsansätze in Physischer Geographie und Humangeographie. Forum ifl 2: 55-67.

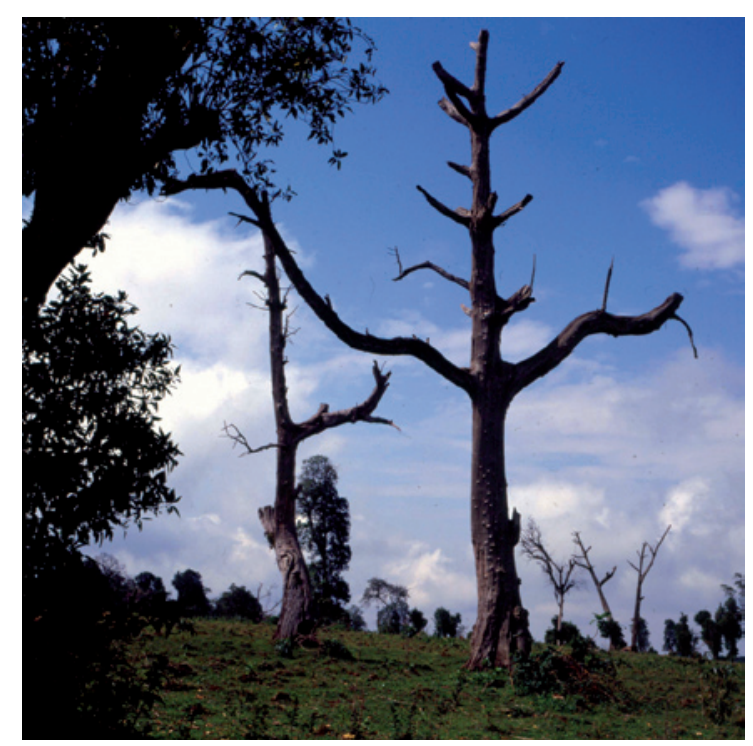

Picture 8-In some places in the "mountain savanna", dead giant trees (esp. Hagenia abyssinica, Prunus africana) are the only clues to the former forests.

Bruner, A., R.E. Gukkison, R.E. Rice \& A.B. Da Fonseca 2001. Effectiveness of Parks in Protecting Tropical Biodiversity. Science 291: 125-128.

Demel, T. 1999. Status of forestry development, conservation and utilisation in Ethiopia. - First meeting of the East African Node of Forestry Research Network for Africa (22-26 May 1999) Nairobi, Kenia.

Drenth, P. J. D. 2008. Social Sciences: Truthful or Useful? European Review 16: 39-53.

Du Toit, J. T., B.H. Walker \& B.M. Campbell 2004. Conserving tropical nature: current challenges for ecologists. Trends in Ecology and Evolution 19: 12-17.

Engelhardt, W. 1984. Tropische Regenwälder - eine globale Herausforderung. Spixiana, Supplement 10: 159-160.

EPA (Environmental Protection Authority [in collaboration with the Ministry of Economic Development and Cooperation]) (ed.) 1997. Environmental Policy of the Federal Democratic Republic of Ethiopia. Addis Ababa.

Friis, I. 1992. Forests and Forest Trees of Northeast Tropical Africa. Kew Bull Additional Series 15: 1-396.

Galvin, M. \& T. Haller (eds.) 2008. People, Protected Areas and Global Change: Participatory Conservation in Latin America, Africa, Asia and Europe. Perspectives of the Swiss National Centre of Competence in Research (NCCR) North-South, University of Bern 3, Bern.

GTZ (Deutsche Gesellschaft für Technische Zusammenarbeit) \& BfN (Bundesamt für Naturschutz), Internationale Naturschutzakademie Insel Vilm (eds.) 2000. Naturschutz in Entwicklungsländern. Neue Ansätze für den Erhalt der biologischen Vielfalt. Heidelberg.

Hirschberger, P. 2007. Die Wälder der Welt - ein Zustandsbericht. Zürich, WWF Schweiz.

IUCN (ed.) 1997. Draft Guidelines for National System Planning for Protected Areas. IUCN World Commission on Protected Areas (WCPA), Gland. 
IUCN (ed.) 2008. Community conserved areas: a bold new frontier for conservation. Available at: www.iucn. org/themes/ceesp/CCA/Index.htlm (accessed: 02/03/09)

Loidi, J. 1994. Phytosociology Applied to Nature Conservation and Land Management. In: Song, Y., H. Dierschke \& X. Wang (eds.). Applied Vegetation Ecology, Proceedings of 35th Symposium IAVS: 17-30.

Markussen, M., R. Buse, H. Garrelts, M.A. MánezCosta, S. Menzel \& R. Markgraf (eds.) 2005. Valuation and Conservation of Biodiversity - Interdisciplinary Perspectives on the Convention on Biological Diversity. Berlin.

Müller-Hohenstein, K. \& A. Abate 2004. Rain Forest Margins and their Dynamics in South-East Ethiopia. In: Gerold, G., M. Fremerey \& E. Guhardja (eds.), Land Use, Nature Conservation and Stability of Rain Forest Margins in South-East Asia. Berlin: 217-238.

Müller-Mahn, D. 2005. Von "Naturkatastrophen" zu „Complex Emergencies“ - Die Entwicklung integrativer Forschungsansätze im Dialog mit der Praxis. In: Müller-Mahn, D. \& U. Wardenga (eds.), Möglichkeiten und Grenzen integrativer Forschungsansätze in Physischer Geographie und Humangeographie. Forum ifl 2: 69-77.

Pankhurst, A. (ed) 2001. Natural Resource Management in Ethiopia. Addis Ababa: Forum for Social Studies.

Plachter, H., D. Bernotat, R. Müssner \& U. Riecken 2002. Entwicklung und Festlegung von Methodenstandards im Naturschutr: Bundesamt für Naturschutz, Bonn-Bad Godesberg. Münster.

Primack, R. \& R. Corlett 2005. Tropical Rain Forests. An Ecological and Biogeographical Comparison. Oxford.

Richter, W.V. 1991. Problems and Limitations of Nature Conservation in Developing Countries. A Case Study in Zaire. In: Erdelen, W. , N. Ishwaran, P. Müller (eds.), Proceedings of the International and Interdisciplinary Symposium "Tropical Ecosystems": 185-193.

Sawhney, P. \& S. Engel 2004. Forest Resource Use by People in Protected Areas and its Implications for Biodiversity Conservation: The Case of Bandhavgarh National Park in India. In: Gerold, G., M. Fremerey \&E. Guhardja (eds.), Land Use, Nature Conservation and Stability of Rain Forest Margins in South-East Asia. Berlin: 239-251.

Schönhuth, M. \& U. Kievelitz 1994. Participatory Learning Approaches - Rapid Rural Appraisal, Participatory Appraisal - an Introductory Guide. Schriftenreihe der GTZ 248. Roßdorf.

Shafer, C.L. 1990. Nature Reserves. Island Theory and Conservation Practice. Washington, DC.

Shaffer, M.L. 1981. Minimum Population Sizes for Species Conservation. Bioscience 31: 131-134.

Simberloff, D.S. 1982. Refuge Design and Island Biogeographic Theory: Effects of Fragmentation. The American Naturalist 120: 41-50.

Sombroek, W. 1994. Introduction to the Philosophy, Concepts and Methods of Ecological-Economic Zoning; its Use as a Basis Instrument for the Conservation and Sustainable Development of Amazonia. In: Tratado de Cooperación Amazónica, Lima (Perú). Secre- taría Pro-Tempore (ed.), Zonificación ecológica-económica: instrumento para la conservación y el desarrollo sostenible de los recursos de la amazonía. Memorias de la Reunión Regional realizada en Manaus, Brazil, 25-29 April de 1994. Lima: 19-20.

Stadler, J. 2000. Schutzgebiete: Anforderungen und Typisierung. In: GTZ \& BfN, Internationale Naturschutzakademie Insel Vilm: Naturschutr in Entwicklungsländern. Neue Ansätze für den Erbalt der biologischen Vielfalt. Heidelberg: 81-86.

Steinhauer-Burkhart, B. \& E. Fischer 1996. Die Vegetation des Parc National de Kahuzi-Biega, Süd-Kivu, Zaire. Erdwissenschaftliche Forschungen 35, Stuttgart.

Stern-Review on the Economics of Climate Change 2008. Available at: http://en.wikipedia.org/wiki/Stern_review (accessed: 11/07/08)

Streit, B. 2007. Was ist Biodiversität? Erfassung, Schutz und Wert biologischer Vielfalt. München: C.H.Beck.

Teutsch, G. 2008. Biodiversität - nutzen und erhalten. Helmholtz-Zentrum für Umweltforschung, UFZ-Spezial April 2008: 3.

Weichhart, P. 2005. Auf der Suche nach der „dritten Säule“. Gibt es Wege von der Rhetorik zur Pragmatik? In: Müller-Mahn, D. \& U. Wardenga (eds.), Möglichkeiten und Grenzen integrativer Forschungsansätze in Physischer Geographie und Humangeographie. Forum ifl 2: 109-136.

\section{Authors}

Klaus Müller-Hohenstein

Prof. Dr. Klaus Müller-Hohenstein studied geography, biology and chemistry in Heidelberg; doctorate and post-doc habilitation in Erlangen; chair in biogeography at the University of Bayreuth (1979-2001). Works on arid areas and tropical mountain ranges. Member of Academia Europaea.

\section{Asferachew Abate}

Dr. Asferachew Abate Abebe studied biology in Addis Ababa, doctorate at the University of Bayreuth, repeated work for NGOs, e.g. the Heinrich Böll Foundation, currently coordinator of a DFG research group in Ethiopia, works on Ethiopian arid and mountain areas.

All photographs (C) by Klaus Müller-Hohenstein. 